\title{
Periphytic algae colonization driven by variable environmental components in a temperate floodplain lake
}

\author{
Tanja Žuna Pfeiffer, Melita Mihaljević*, Filip Stević and Dubravka Špoljarić \\ Department of Biology, Josip Juraj Strossmayer University of Osijek, Cara Hadrijana 8/A, 31000 Osijek, Croatia
}

Received 27 November 2012; Accepted 29 May 2013

\begin{abstract}
The colonization of periphytic algae in a temperate floodplain was studied in Lake Sakadaš, a part of a fluvial floodplain along the Danube River. An in situ investigation, using artificial substrata, was started after extremely high spring flooding and was carried out during long-lasting summer floods (July-August 2010). The physical and chemical environment was variable and large stands of metaphyton, submersed and floating macrophytes were spread along the lake. The periphyton development was initiated on the first day of exposition and algal abundance increased exponentially till day 27. Directional changes in the relative abundance of algal species, shown by the results of the non-metric multidimensional scaling, indicate a pattern of short-term sequences in algal colonization. The initial attachment of planktonic cyanobacteria and unicellular diatoms (initial phase, days 1-3) to the biofilm matrix was followed by the development of the filamentous chlorophytes, Cladophora glomerata and Oedogonium spp. (intermediate phase, days 6-15) and then by stalk-forming diatoms particularly Gomphonema spp. (late phase, days 18-33). According to the redundancy analyses, water temperature and oscillations of Danube water level that define the flooding pattern had the most significant influence on algal colonization. Flood-induced spreading of metaphyton firstly supported the rapid progress of algal colonization towards a climax community, while later, metaphyton together with macrophytes disrupted algal community by increasing the mechanical injuries, shading and grazing pressure. Consequently, algal abundance and community structure were returned to the intermediate phase of colonization.
\end{abstract}

Key words: Danubian floodplain / artificial substratum / colonization / algae / periphyton biomass

\section{Introduction}

Periphyton is of growing interest worldwide since it has been recognized as an excellent indicator for changes occurring in the aquatic environment (Azim et al., 2005). It responds rapidly to water quality changes such as increasing nutrient concentrations, input of organic compounds, pesticides and heavy metals (Guasch et al., 2003; Gaiser et al., 2004; Gottlieb et al., 2006; Morin et al., 2010).

In a wide range of freshwater ecosystems, colonization process and succession of periphytic algae follow a similar pattern. The deposition of dissolved organic substances, rapid bacterial attachment and rapid colonization of prostrate diatoms followed by perpendicularly standing algae and finally by algae-forming filaments or having a basal stalk are well-known sequences of periphyton

\footnotetext{
*Corresponding author: mmihaljevic@biologija.unios.hr
}

development (see Azim and Asaeda, 2005 for review). According to the specific adherence strategies and ability to acclimate to the disturbance and nutrient resource supply, periphytic algae are classified as ruderal (R), competitive (C) and stress-tolerant (S) (Biggs et al., 1998). R-selected taxa have small-sized cells and are rapid colonists adapted to disturbed habitats with variable enrichment. C-selected taxa have an upright growth form and thus compete most effectively for nutrients and light while S-selected taxa have a high stature and nitrogen-fixing capacity that allows them to tolerate oligotrophic conditions. Generally, R-selected taxa dominate early successional communities, whereas $\mathrm{C}$ - and S-selected taxa become more abundant in older communities. These strategies suggest that periphytic algae colonization is analogous to higher plant succession in terrestrial environments (Hoagland et al., 1982; Biggs et al., 1998). Colonization process has been found to be influenced by different factors such as wave energy, 
type of the substrata, as well as size, immigration and reproduction rate of periphytic organisms (Ács and Kiss, 1993; Ács et al., 2000; Albay and Akçallan, 2003). Many recent studies have been undertaken to determine the responses of periphyton to the changes in hydrologic levels in tropical floodplains and results clearly showed that flood pulse constitutes the principal force acting directly on the colonization processes and successive patterns of periphytic communities (Rodrigues and Bicudo, 2001; Algarte et al., 2009; Murakami et al., 2009). However, seasonality of the periphytic algae colonization has not yet been investigated in detail. According to some previous investigations, periphyton is often dominated by diatoms in winter, spring and autumn and by green algae and Cyanobacteria in summer (Liboriussen, 2003). Moreover, we found that during the periphyton colonization in temperate floodplain under the spring conditions diatoms were the most abundant species. Colonization progressed from the initial settlement of planktonic species and unicellular horizontally positioned diatoms, through the stalk forming and finally to vertically positioned species (Mihaljević and Žuna Pfeiffer, 2012).

Floodplains are highly dynamic ecosystems where the flood pulses were widely recognized as the most important factor for creating and maintaining habitat heterogeneity and ecosystem processes (Tockner et al., 2000). During flooding, the floodplain becomes inundated and the floodplain lakes become connected to the main river while during low water the floodplain lakes become disconnected from the main stream and develop according to the local conditions (Ward and Stanford, 1995). Aquatic plants, usually well developed in floodplains, may have a significant influence on periphyton communities. Development of aquatic plants may shift algal growth from the water column or sediments to plant surfaces (Goldsborough and Robinson, 1996). However, periphyton biomass on different types of substrates may decrease in the presence of macrophytes due to the high competition for nutrients, high abrasion and low light availability (Higgins and Hann, 1995). Furthermore, macrophytes produce and release allelopathically active compounds that may influence the composition of algal communities (Gross et al., 2003; Addisie and Medellin, 2012).

Considering the scarcity of information on colonization processes of periphytic communities in temperate floodplains, we conducted an in situ investigation of periphytic algae colonization in Lake Sakadaš, a part of a fluvial floodplain along the Danube River (Kopački Rit Nature Park, Croatia). Focusing on short-term changes in algal community structure, we tried to explore the importance of season-driven variables on periphyton colonization in the summer period. Since summer flooding events became frequent in the last decade, we expected them to occur and tried to find out how hydrologically induced changes of environment will influence progress in algal colonization.

\section{Materials and methods}

\section{Study site}

The Kopački Rit Nature Park is a fluvial floodplain along the Danube River (1383-1410 km), located in Northeast Croatia. The inundation area, with permanent marshes/pools, ponds, swamps on organic soils, shallow lakes and river side arms as dominant wetland types, covers approximately $18 \mathrm{~km}^{2}$. The flooding of the floodplain area begins when the Danube water level at the gauge station (river $1401.4 \mathrm{~km}$ ) rises above $3 \mathrm{~m}$ (Mihaljević et al., 1999).

The colonization study was conducted in Lake Sakadaš (Fig. 1), which is located in the western part of the floodplain and it is in a direct hydrological connection with the river main channel through a system of natural channels (total length ca. $10 \mathrm{~km}$ ). The lake is the deepest depression in the floodplain with an average depth of about $5 \mathrm{~m}$ and a surface water area of about $0.15 \mathrm{~km}^{2}$. Submerged macrophytes (Ceratophyllum demersum L., Myriophyllum spicatum L. and Potamogeton gramineus L.) are well developed in the shallow parts of the lake. The lakeshore is infested with common red (Phragmites communis Trin.), adjoined by floodplain forests of black poplar (Populus nigra L.) and white willow (Salix alba L.). The results of water quality monitoring during the past decades (Mihaljević et al., 1999, 2009; Horvatić et al., 2003; Mihaljević and Stević, 2011) have shown that the lake was in a eutrophic/ hypertrophic state.

\section{Research setting}

Artificial substrata in the form of glass slides $(6 \times 14 \mathrm{~cm})$, fastened to a wood frame and oriented vertically (long sides were parallel with the lake bottom) in the water column, were placed into the lake at a depth of $0.20 \mathrm{~m}$ beneath the water surface. Since the water level of the floodplain lake fluctuates, the slides holder was constructed to compensate for those changes. Thus, the wooden frame was elevated above the water surface using sunken buoys and fastened with rope to stone blocks bedded in the lake bottom. The rope was long enough to enable the holder to freely slide vertically. In that way, the glass slides maintained the same position in the water column $(0.20 \mathrm{~m}$ beneath the water surface) during the colonization study. The slides were sampled randomly after the first day of incubation and again at three-day intervals from July 12 to August 23 of 2010. A total of 45 samples were collected. During each sampling event, three replicates were taken and analyzed separately. The periphyton on each glass slide was split into the three parts. One part was scraped using a razor blade into $100 \mathrm{~mL}$ of sterile water, gently sonicated for $2 \mathrm{~min}$ and then fixed by the addition of $4 \%$ formaldehyde. The suspension was used for qualitative and quantitative algal assay. The second part of the periphyton was scraped from 


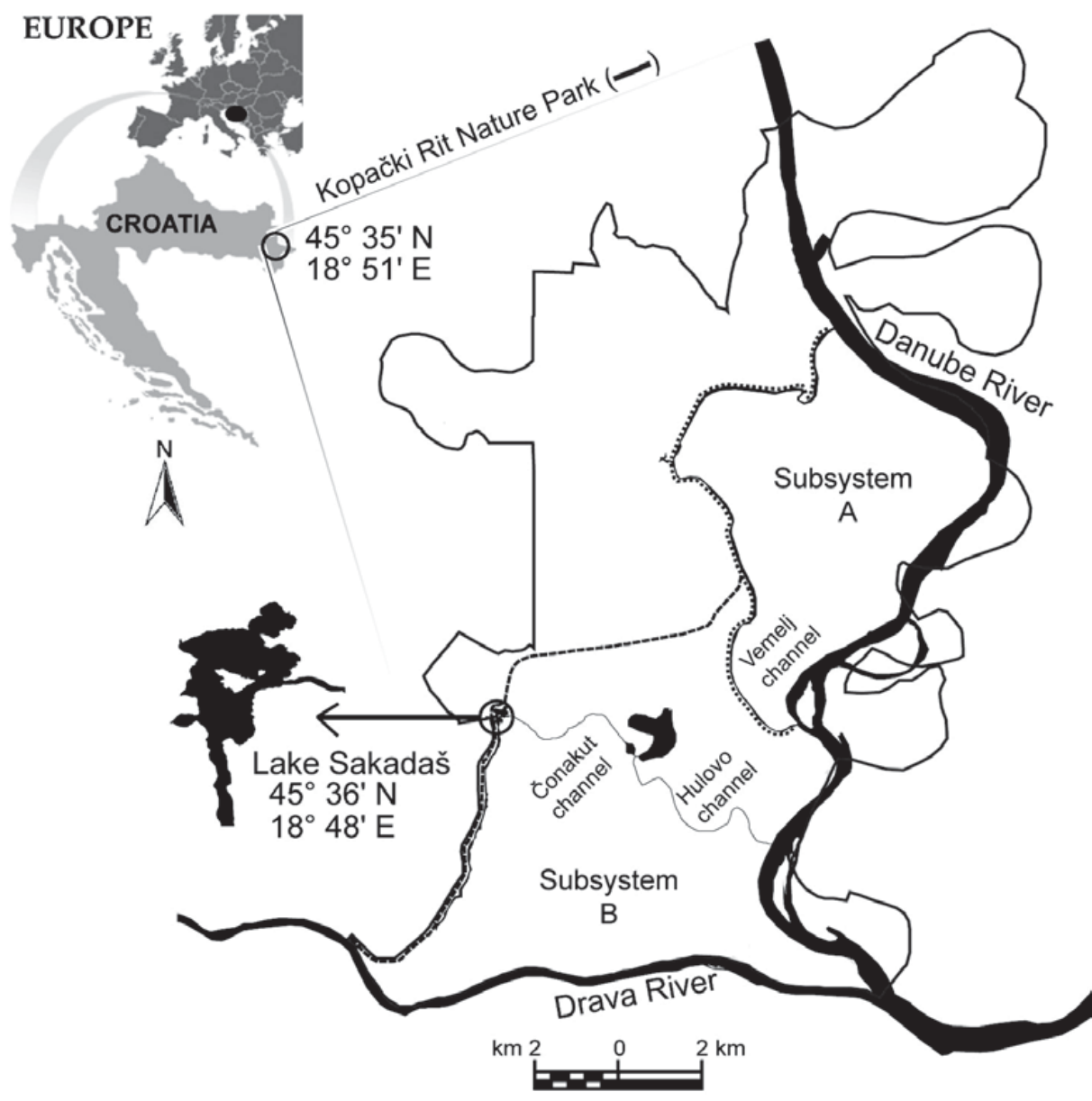

Kopački Rit Nature Park

Subsystems of the inundation area

the glass slide into tap-water and used to determine chlorophyll concentration. The third part was used for periphyton biomass analysis including dry mass (DM), ash mass (AM) and ash-free dry mass (AFDM).

\section{Chemical analyses}

Water samples were taken simultaneously with the periphyton samples at a depth of $0.20 \mathrm{~m}$ beneath the water surface. Water temperature (WT), dissolved oxygen (DO), $\mathrm{pH}$ and conductivity (Cond) were measured in the field using WTW Multi 340i (Wissenschaftlich-Technische Werkstätten, Weilheim, Germany) portable instrument. Water transparency (SD) was measured with Secchi disc. Water chemical variables, ammonium $\left(\mathrm{NH}_{4}^{+}\right)$, nitrates $\left(\mathrm{NO}_{3}^{-}\right)$, nitrites $\left(\mathrm{NO}_{2}^{-}\right)$, total nitrogen $(\mathrm{TN})$, total phosphorus (TP) and periphyton biomass (DM, AM and AFDM) were analyzed in the laboratory according to APHA (1992).

\section{Algal community analysis}

Chlorophyll a (Chl a) and chlorophyll c (Chl c) concentrations were estimated according to Komárková (1989). Periphyton algal species were identified with a light microscope (Carl Zeiss Jena) at two magnifications $(400 \times, 1000 \times)$ and using standard literature for species determination (Huber-Pestalozzi, 1942; Hustedt, 1976; Hindak et al., 1978; Anagnostidis and Komárek, 1985, 1988; Komárek and Anagnostidis, 1989). For quantitative analyses, the individuals of each species (filament or colony was considered to be equal to one individual) were counted (Sekar et al., 2004; Szabó et al., 2008) on a millimeter grid with an area of $1 \mathrm{~cm}^{2}$ (Stilinovic and Plenković-Moraj, 1995). Only diatom taxa were counted as a group. For detail diatom identification, samples were cleaned in distilled water, $\mathrm{H}_{2} \mathrm{O}_{2}$ and $\mathrm{HCl}$ treated, washed and embedded in Canada balsam. In each sample, 300-400 valves were counted and identified to species level. The total number of each diatom species was calculated 
as a ratio between the number of diatom valves counted on samples embedded in Canada balsam and the total number of diatoms counted on a millimeter grid. Since the periphyton was scraped from artificial substrates into the certain volume of tap water, it was taken into account in the final conversion of the abundance of each species per unit area (ind. $\mathrm{cm}^{-2}$ ).

The dominant species was estimated from the percentage contribution of individual species to total algal abundance. Only those species which had a minimum of $5 \%$ contribution to total abundance were considered to be dominants.

\section{Statistical analyses}

The obtained data were processed using a set of multivariate techniques supplied by the PRIMER 5 software (Clarke and Warwick, 2001). Non-metric multidimensional scaling (NMDS) was used to display similarity between periphytic algal communities during the colonization. Analysis of similarities (ANOSIM) was used to quantify the significance of the separation among the periphyton algal groups. NMDS and ANOSIM were applied on the Bray-Curtis similarity coefficient based on the absolute algal abundance data. Before computation, algal abundance was logarithmically transformed $(\log (x+1))$ to obtain the normal distribution. The contribution of different algal species to the average dissimilarity between groups was determined using the SIMPER procedure.

The potential effects of environmental variables on the periphytic algal community were examined by redundancy analysis (RDA). RDA was selected according to an initial detrended correspondence analysis (DCA) with gradient length $<3.0$, which suggested a linear ordination model (Lepš and Šmilauer, 2003). The environmental dataset was reduced to nine variables, including Danube water level (WL), SD, WT, DO, Cond, $\mathrm{NO}_{2}^{-}, \mathrm{NO}_{3}^{-}, \mathrm{NH}_{4}^{+}$and TP. Variables TN and $\mathrm{pH}$ were excluded due to the strong inter-correlation $(r>0.95 ; P<0.05)$. Environmental variables were log-transformed and submitted to the stepwise forward selection procedure in which the statistical significance of each variable was tested by the Monte Carlo permutation test (499 permutations) at a cutoff point of $P=0.05$. Algal abundances data were square-root transformed before analysis. RDA with the option 'center and standardize by species' was used. For the species composition, this option causes each of the species to have the same weight in the analysis. To asses proportion of variance explained by the seasonal and hydrologically driven variables (WL, SD, WT, DO, Cond) from those of nutrients $\left(\mathrm{NO}_{2}^{-}, \mathrm{NO}_{3}^{-}, \mathrm{NH}_{4}^{+}, \mathrm{TP}\right)$, a series of RDAs and partial RDAs were carried out following the variance partitioning technique (Borcard et al., 1992). Partial RDAs were used to separate and examine the relative importance of each group of explanatory variables for the species data. Variation partitioning was performed in several steps: (i) RDA of the species matrix constrained by the nutrients, (ii) RDA of the species matrix constrained by the seasonal and hydrologically driven variables, (iii) partial RDA of the species matrix constrained by the nutrients and using the seasonal and hydrologically driven variables as covariables, and (iv) partial RDA of the species matrix constrained by the seasonal and hydrologically driven variables and using the nutrients as covariables. In order to summarize the results in a single graph, species and the significant environmental variables were shown in the ordination diagram. All the calculations were performed with the CANOCO version 4.5 program packet (Biometrics-Plant Research International, Wageningen, The Netherlands).

The species-time data were fitted to the MacArthurWilson equilibrium model (MacArthur and Wilson, 1963) using non-linear squares regression. Assessment of equilibrium species member $\left(S_{\text {eq }}\right)$ and the colonization rate constant $(G)$ were received directly from analysis. To define stabilization time the following equation was used: $S_{\mathrm{t}}=S_{\mathrm{eq}}\left(1-\mathrm{e}^{-G t}\right)$, where $S_{\mathrm{t}}$ is the number of species at time $t, S_{\mathrm{eq}}$ is the equilibrium species number, $G$ is the coefficient of the colonization current and $t$ is the time. The stabilization time of algal colonization on glass slides, expressed in days, is the moment when the regressive straight line aligns with the number of species in the asymptote.

Pearson's correlation coefficient was used to analyze the correlation between environmental variables. Pearson's correlation coefficients and non-linear squares regression were assessed using Statistica 7.0 (StatSoft, Inc.).

Percent of periphytic organic mass (a ratio of AFDM:DM) and inorganic mass (a ratio of AM:DM) were calculated to describe the variation in organic/ inorganic content of periphyton. The Autotrophic Index (AI), a ratio of organic biomass and $\mathrm{Chl}$ a, was calculated according to APHA (1992), in order to detect changes in the trophic nature of the periphytic community. AI values higher than 200 indicate heterotrophic association, whereas lower values indicate an autotrophic nature of periphytic community (Lakatos, 1989).

\section{Results}

\section{Environmental conditions}

The colonization study started at the end of longlasting (May-July) and extremely high flooding when the Danube water level reached almost $8 \mathrm{~m}$ (Fig. 2). There was another huge flood that started at the end of July and continued until the end of the colonization study. Owing to the influx of floodwaters into the lake the significant fluctuations of environmental variables were established (Fig. 3, Table 1). The lake water depth was continuously above $6 \mathrm{~m}$ and increased up to $8.66 \mathrm{~m}$. Secchi depth varied between 0.74 and $1.51 \mathrm{~m}$ and showed a significant positive correlation with the Danube water level $(r=+0.61$; $P<0.05)$. Chl a concentration ranged from 22.04 to $68.09 \mu \mathrm{g} . \mathrm{L}^{-1}$. A significant negative correlation between 


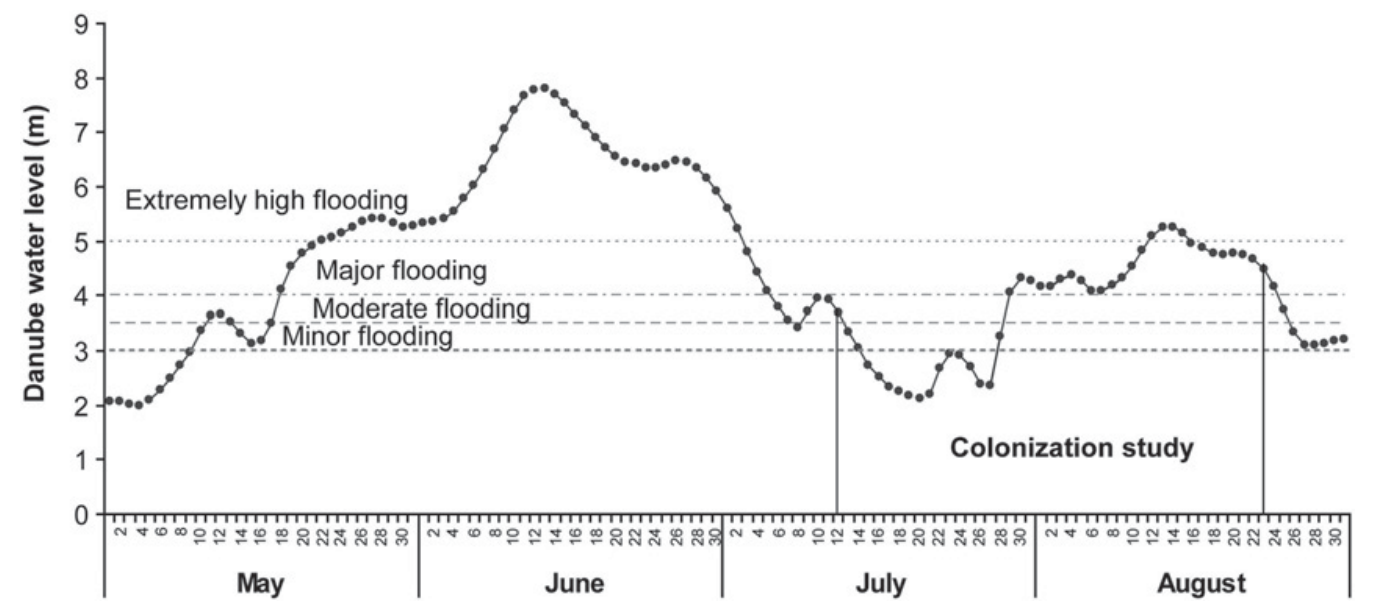

Fig. 2. Course of the Danube water level at river $1401.4 \mathrm{~km}$ in the period May-August, 2010.

Chl a concentration and water depth was recorded $(r=-0.52 ; P<0.05)$. Water temperature fluctuated from 22 to $29.5^{\circ} \mathrm{C}$. The $\mathrm{pH}$ values, always above 7 , indicated alkaline conditions. Highly fluctuating dissolved oxygen values $\left(2.34-13.62 \mathrm{mg} . \mathrm{L}^{-1}\right)$, conductivity (377-758 $\mu \mathrm{S} . \mathrm{cm}^{-1}$ ) and nutrients (TP: 0.05-0.48 mg. $\mathrm{L}^{-1}$; TN: 0.67-5.81 mg. $\mathrm{L}^{-1}$ ) were found. Conductivity showed a significant correlation with ammonium $(r=+0.63$; $P<0.05)$, nitrites $(r=-0.54 ; P<0.05)$ and total phosphorus $(r=+0.89 ; \quad P<0.05)$. High concentrations of $\mathrm{NO}_{2}^{-}$and $\mathrm{NO}_{3}^{-}$were found under the flooding conditions. $\mathrm{NO}_{2}^{-}$showed significant correlation with oxygen concentration $(r=+0.71 ; P<0.05)$ and $\mathrm{pH} \quad(r=+0.69$; $P<0.05)$, whereas $\mathrm{NO}_{3}^{-}$significantly correlated with TN $(r=+0.95 ; P<0.05)$.

\section{Periphyton structural parameters}

Periphyton DM (Fig. 4A) continuously increased from an initial $0.05 \pm 0.01 \mathrm{mg}^{-\mathrm{cm}^{-2}}$ and reached a maximal value $\left(4.45 \pm 0.62 \mathrm{mg} . \mathrm{cm}^{-2}\right)$ on day 33 . A significant decrease in DM was observed from day 36 till the end of study. Oscillations in AFDM and AM (Figs. 4A and $\mathrm{B}$ ) indicated the significant changes in organic/inorganic content of periphyton during the colonization study. During the first 12 days, periphyton was mostly composed of organic matter (AFDM: $0.04 \pm 0.01-0.20 \pm 0.05 \mathrm{mg} . \mathrm{cm}^{-2} ;$ AM: $0.005 \pm 0.004$ $0.06 \pm 0.04 \mathrm{mg} . \mathrm{cm}^{-2}$ ), whereas from days 27 to 36 there was a prevalence of inorganic matter (AM: $1.07 \pm 0.63-$ $3.35 \pm 0.44$ mg.cm ${ }^{-2}$; AFDM: $0.65 \pm 0.32-1.11 \pm 0.18$ mg.cm ${ }^{-2}$ ). A high content of organic matter was established again on days 39-43. Chl a concentration (Fig. 4C) continuously increased to day $24(5.03 \pm 0.17$ $\left.\mu \mathrm{g} . \mathrm{cm}^{-2}\right)$. There was a decrease in Chl a on days 39 and 43. Chl c concentration (Fig. 4C) continuously increased until day $27\left(0.05 \pm 0.007-17.25 \pm 1.15 \mu \mathrm{g} . \mathrm{cm}^{-2}\right)$ and then decreased for the remainder of the colonization study.
The AI values oscillated between 36.51 and 1089.99 demonstrating the changes in relative contribution of autotrophic and heterotrophic organisms in periphytic communities (Fig. 4D). AI values higher than 200 on days $1,3,24$ and 33 pointed to a prevalence of heterotrophic communities.

\section{Periphyton algal community structure}

A total of 214 algal taxa were identified during the study period. Chlorophyceae made up the largest taxonomic group (106 taxa), followed by Bacillariophyceae (42 taxa), Euglenophyta (26 taxa), Cyanobacteria (25 taxa) and Xanthophyceae (9 taxa). Chrysophyceae and Pyrrophyta were represented with 3 taxa each. The number of algal taxa continuously increased from 38 taxa on the first day of colonization to 134 taxa on day 27 (Fig. 5A). Among them, 16 taxa were found on each of the sampling days, while 45 taxa were recorded only once.

The stabilization time of algal colonization (based on algal diversity) according to regression values of periphyton algal colonization dynamics $\left(S_{\mathrm{eq}}=110.31\right.$, $G=-0.26, R=0.9385$ ) was 18 days.

Algal abundance continuously increased through the study from an initial of $0.30 \times 10^{4} \pm 0.07-47.51 \times 10^{4} \pm$

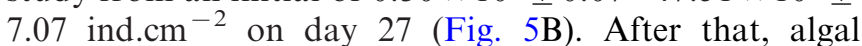
abundance significantly decreased. The extremely low algal abundance $\left(2.94 \times 10^{4} \pm 0.86-4.26 \times 10^{4} \pm 0.23\right.$ ind.cm $\left.^{-2}\right)$ was found on day 36 onward.

NMDS (Fig. 6) revealed three distinctive groups with additional subgroups, indicating quantitative changes in the periphyton communities with respect to exposure time. The first group (I) encompassed the first three days of colonization. The second group (II) included two subgroups: days 6-15 (subgroup IIa) and days 36-39 (subgroup IIb). The third group (III) also encompassed two subgroups: days 18-33 (subgroup IIIa) and day 43 as a subgroup IIIb. According to the ANOSIM, significant differences were found between the periphytic algal groups 

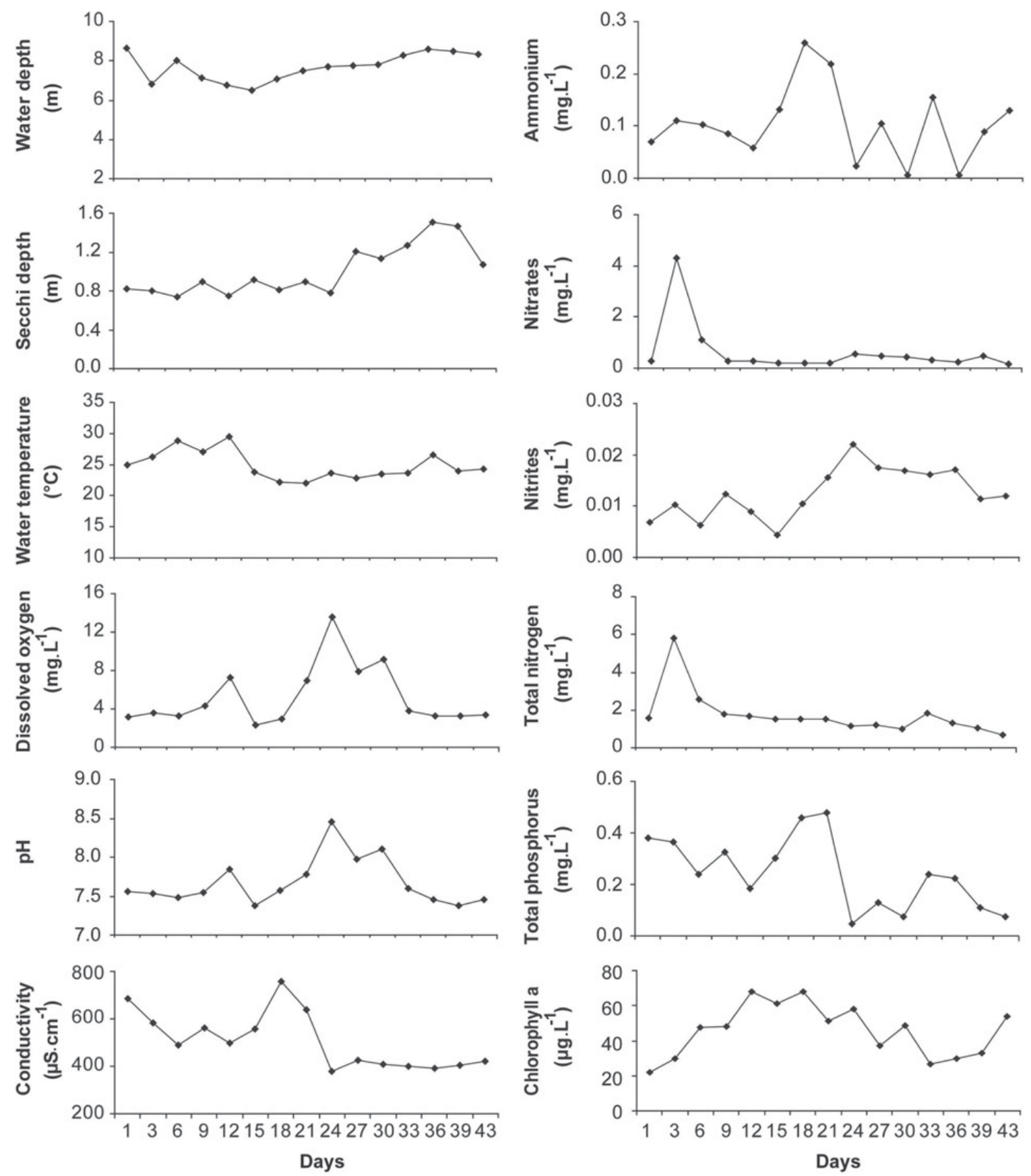

Fig. 3. Limnological variables in the floodplain lake during the colonization period (day 1-day 43).

(global $R=0.876 ; P<0.05$ ). Results of the SIMPER routine indicated that xanthophytes $(16.33 \%)$ and chlorophytes $(27.74 \%)$ were the most important in contributing to the dissimilarity between the first and second group, while Gomphonema spp. contributed the most (>80\%) to the dissimilarity between groups I and III as well as between groups II and III.

A total of 14 algal taxa reached a relative abundance of more than 5\% (Fig. 5C). Planktonic cyanobacteria Aphanocapsa delicatissima W. West et G. S. West and chlorophyta Asterococcus superubs (Cienk) Scherff., dominated on days 1-3 (Fig. 5C). Diatoms Achnanthidium minutissimum (Kütz.) Czar., Gomphonema parvulum (Kütz.) Kütz., Stephanodiscus hantzschii Grun. and Encyonema ventricosum (Agardh) Grun. were also dominant species at the beginning of colonization. A shift in dominance took place in the period from days 6 to 15 (Fig. 5C) and the most abundant were Xanthophyceae, Characiopsis acuta (A. Br.) Borzi and large filamentous green algae, Cladophora glomerata (L.) Kütz. and Oedogonium sp. Further algal colonization (from days 18 to 33) was characterized by high abundance of chlorophytes Characium ornitocephalum $\mathrm{A}$. Br. and xanthophytes Characiopsis borziana Lemm. (Fig. 5C). Diatoms 


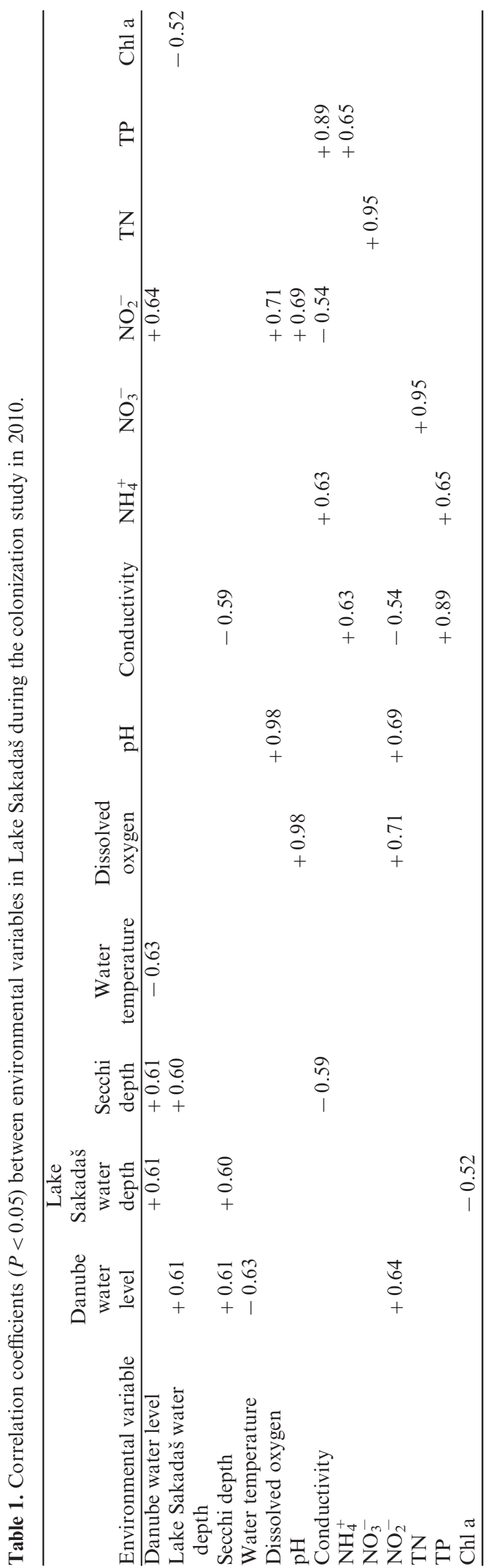

were continually present in periphytic communities with significant abundance. The most abundant were Gomphonema olivaceum (Hornem.) Bréb. and particularly G. parvulum, which comprised 76.89 and $72.65 \%$ of the total algal abundance on days 30 and 33 (Fig. 5C). The shift in algal composition was accompanied by sharp decline in periphyton biomass from days 36 to 43 . Over this period, G. parvulum comprised $17.17-37.10 \%$ of the total algal abundance while the changes of other dominant algal species were as follows: $C$. ornitocephalum, Oedogonium sp., G. olivaceum on day 36; C. ornitocephalum, Cyclotella meneghiniana Kütz., G. olivaceum on day 39; A. minutissimum and Halamphora veneta (Kütz.) Lev. on day 43.

\section{Environmental variables and periphyton}

The two main axes of RDA explaining $93.9 \%$ of the total variance (axis 1: $61.9 \%$; axis 2: $32.0 \%$ ) indicate a significant relationship between environmental variables and periphytic algal abundance data (Fig. 7). Most of the variance contained in the first RDA axis is described by the following variables: $\mathrm{NO}_{2}^{-} \quad\left(r_{\mathrm{RDA} 1}=0.6907\right.$, $P<0.05)$, WT $\left(r_{\mathrm{RDA} 1}=-0.6226, P<0.05\right)$ and $\mathrm{DO}$ $\left(r_{\mathrm{RDA} 1}=0.5867, P<0.05\right)$. In the second RDA axis, most of the variance is explained by the WL $\left(r_{\mathrm{RDA} 2}=0.6332\right.$, $P<0.05$ ). Species $C$. glomerata, $A$. delicatissima and $C$. acuta reached high abundance at the beginning of colonization period and their development was associated with high water temperature and low Danube water level. High abundance of $A$. minutissimum at the end of colonization was associated with high Danube water level. $G$. parvulum and $C$. ornitocephalum closely correlated with high concentration of nitrites, whereas $S$. hantzschii correlated with dissolved oxygen. In order to separate the effects of the forward selected nutrients $\left(\mathrm{NO}_{2}^{-}, \mathrm{NO}_{3}^{-}\right.$, $\left.\mathrm{NH}_{4}^{+}, \mathrm{TP}\right)$ and seasonal and hydrologically driven variables (WL, SD, WT, DO, Cond) and assess their relative importance in determining algal species composition of periphyton community, a series of RDAs and partial RDAs were used (Fig. 8). A first RDA examined the effect of nutrients on periphytic algae and selected nitrites as significant variable, which accounted for $21 \%$ of the total variance. A second RDA considered effect of the seasonal and hydrologically driven variables on the algal communities. Danube water level, water temperature and dissolved oxygen were significant variables which explained $43 \%$ of the total variance. Partial RDA using nutrients as explanatory variables and seasonal and hydrologically driven variables as covariables explained $25 \%$ of total variance. Ammonium had a significant effect on the algal communities, explaining $12 \%$ of the total variance. Partial RDA using seasonal and hydrologically driven variables as explanatory variables and nutrients as covariables explained $33 \%$ of total variance. Danube water level had the significant influence and explained $13 \%$ of total variance. All RDAs and partial RDAs performed suggest that seasonal and hydrologically driven 


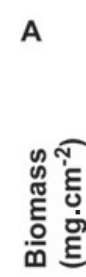

A

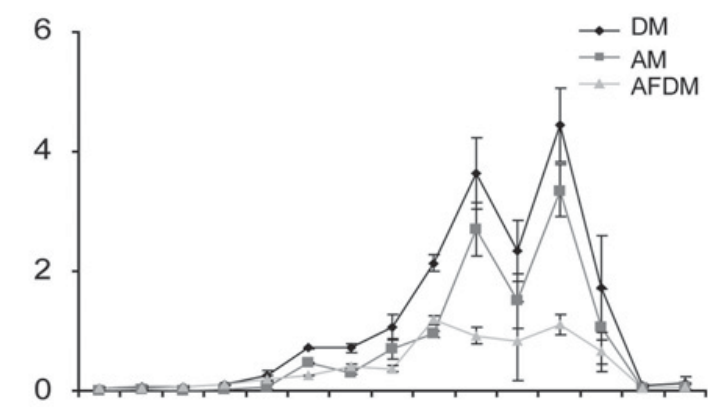

B

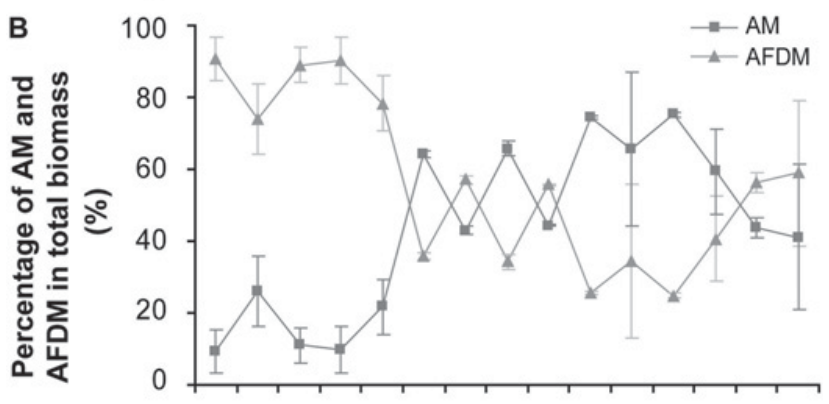

\section{$\circ$}

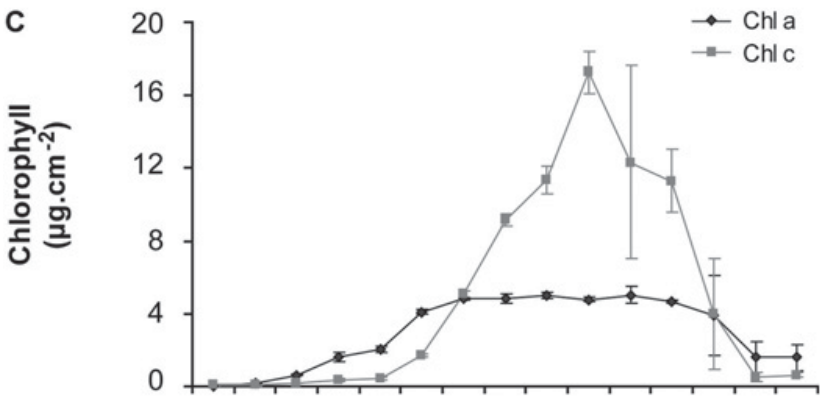

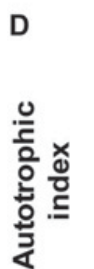

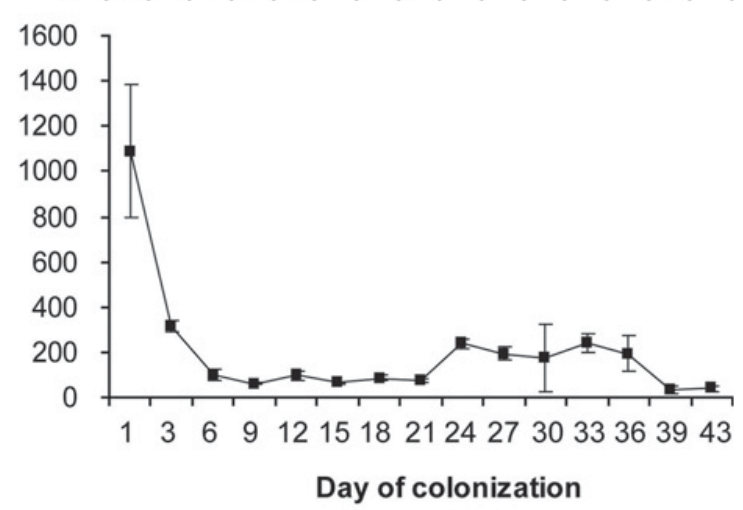

Fig. 4. Temporal variations of periphyton dry mass (DM), ash mass (AM) and ash-free dry mass (AFDM) (A), percentage of AM and AFDM in total periphyton biomass (B), periphyton chlorophyll a (Chl a) and chlorophyll c (Chl c) concentrations (C), and autotrophic index (D) during the colonization period (day 1-day 43). Bars represent one \pm standard deviations $(n=3)$.

variables have higher influence on periphytic algae than nutrient concentrations.

\section{Discussion}

Flooding dynamics can be recognized as one of the most important factors for understanding the lake
A

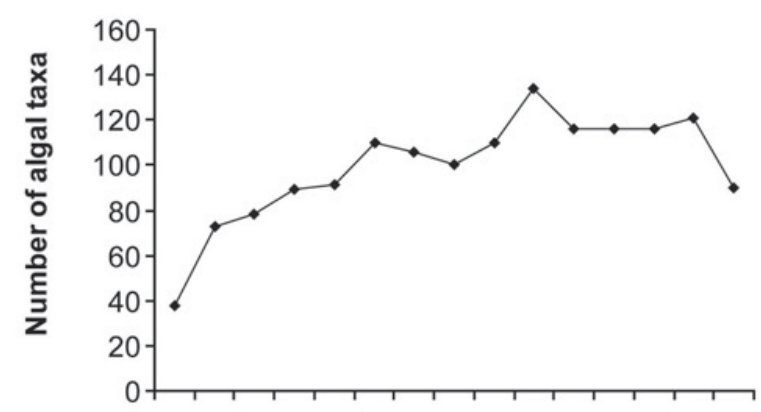

B

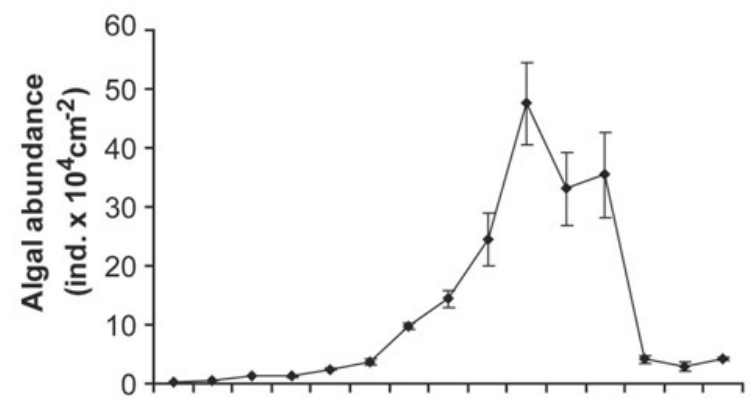

C

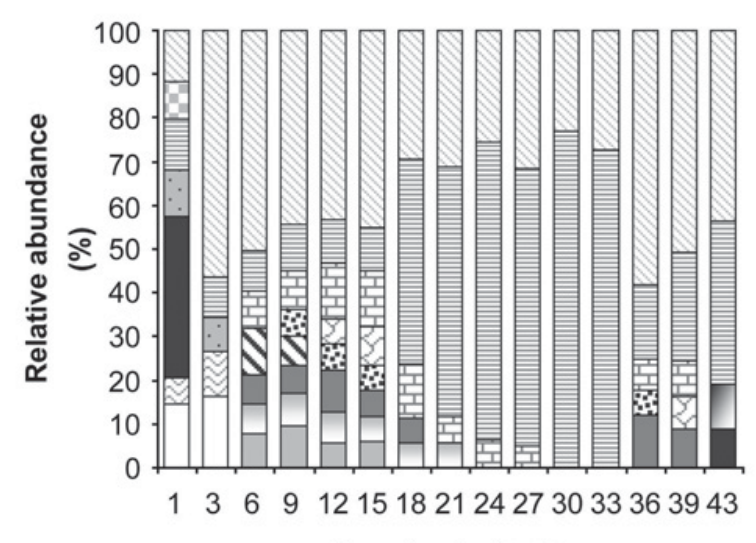

\section{Legend: $\square$ APHDEL $\square$ CHAACU $\boxminus$ CHABOR $\square$ CHAORN Q $⿴$ ASTSUP $\boldsymbol{\Delta}$ CLAGLO 圈 OEDSP $\square$ ACHMIN $\square$ HALVEN $\square$ CYCMEN $\square$ ENCVEN GOMPAR $\square$ STEHAN $\square$ Other}

Fig. 5. Variations in the total number of algal taxa (A), algal abundance (B), and relative abundance of dominant periphytic algae (C) during the colonization period (day 1-day 43). Bars represent one \pm standard deviations $(n=3)$. Legend: $A$. delicatissima - APHDEL; C. acuta-CHAACU; C. borziana CHABOR; C. ornitocephalum - CHAORN; A. superubs ASTSUP; C. glomerata - CLAGLO; Oedogonium sp. OEDSP; A. minutissimum - ACHMIN; H. veneta - HALVEN; C. meneghiniana - CYCMEN; E. ventricosum - ENCVEN; G. olivaceum - GOMOLI; G. parvulum - GOMPAR; S. hantzschii-STEHAN.

environment. Our investigation started after the extremely high and long-lasting flood pulse in June, which caused the input of nutrients and organic matter from terrestrial biotopes resulting in an increase of nutrient concentrations and conductivity. The lake water depth was relatively low at the beginning of the study and thus, combination of light and nutrients created favorable conditions for 
Late phase

(III)

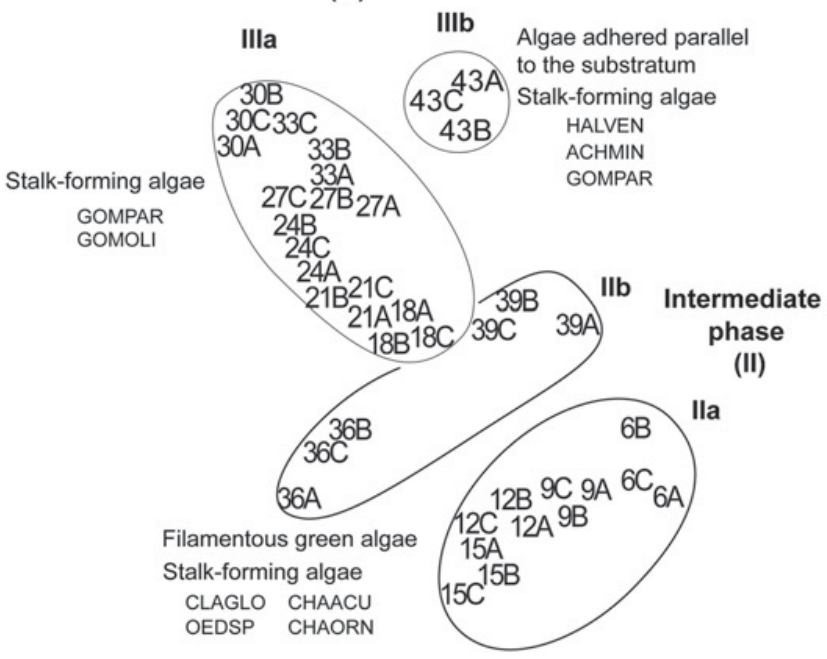

Stress: 0.11

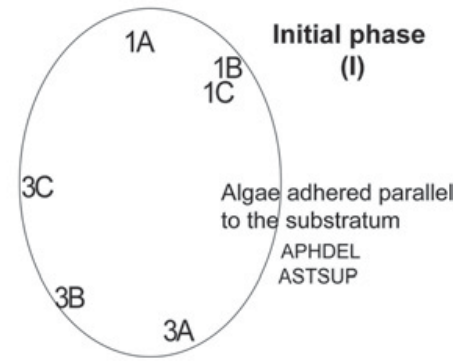

Fig. 6. NMDS plot based on periphytic algal abundance. Number indicates day of colonization while character indicates glass slides. Roman characters indicate colonization sequences.

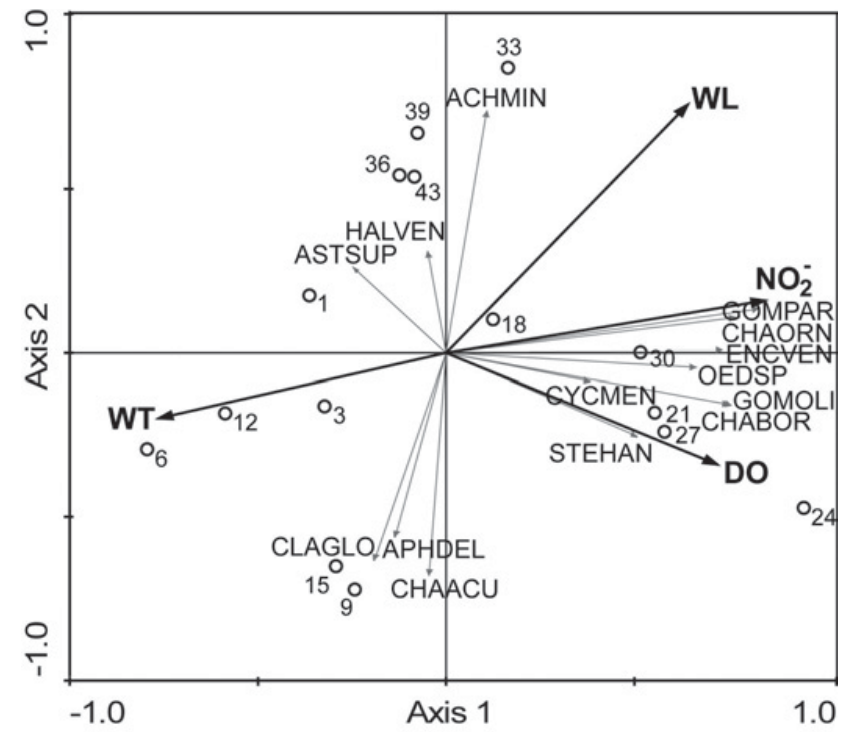

Fig. 7. First and second axes of RDA based on abundance of periphytic algal taxa in Lake Sakadaš during the colonization study (2010). Environmental variables (WL - Danube water level, WT - water temperature, DO - dissolved oxygen, and $\mathrm{NO}_{2}^{-}$- nitrites) are represented with black arrows; dominant periphytic algae vectors are represented with grey arrows; samples are represented with a symbol - open circle represents day of colonization. (See Fig. 5 for species code.)

rapid algal colonization on the exposed substrata. The number of algal taxa increased through the colonization and a stable community was achieved on day 18, as shown by the MacArthur-Wilson equilibrium model. The stabilization of algal community was rapid as compared with the colonization in spring (Mihaljević and Žuna Pfeiffer, 2012) and could be associated with higher water temperatures and longer diurnal period.

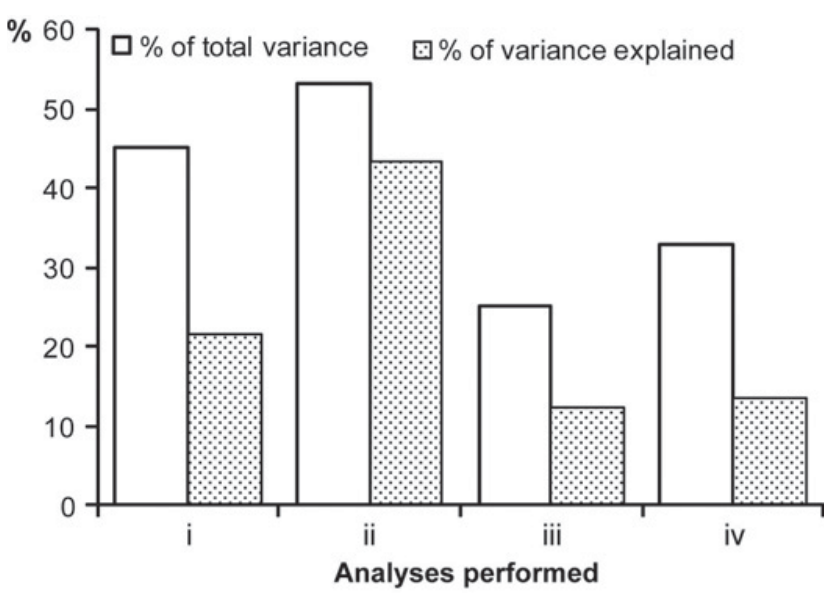

Fig. 8. Percent of total variance and variance explained in the periphytic algal community data by redundancy and partial redundancy analyses. Variation partitioning was performed in several steps: (i) RDA of the species matrix constrained by the nutrients, (ii) RDA of the species matrix constrained by the season-driven variables, (iii) partial RDA of the species matrix constrained by the nutrients and using the season-driven variables as covariables, and (iv) partial RDA of the species matrix constrained by the season-driven variables and using the nutrients as covariables.

Periphyton algal abundance increased exponentially through the colonization (Fig. 5B). Simultaneously, a directional change in the relative abundance of species in a community occurred, indicating a pattern of short-term sequences of algal colonization (Fig. 6). The first sequence, e.g., initial phase (days 1-3), was characterized by planktonic Cyanobacteria (A. delicatissima) and chlorococcal algae (A. superbus) followed by unicellular diatoms (A. minutissimum and G. parvulum) which directly "attach" onto the developed biofilm. According to Biggs et al. 
(1998) these diatom species have high immigration rates and are classified as R-strategists. Thus, immigration was probably the most important process in the initial sequence of algal colonization, as it was found in many different freshwater habitats (e.g., Ács et al., 2000; Felisberto and Rodrigues, 2010). Large filamentous green algae and stalk-forming species started to grow inside the biofilm very early, during the intermediate phase (days 6-15) and the reproduction became responsible for the continuous increase in algal abundance (Ács et al., 2007). The well developed layer of $C$. glomerata expanded additional surface for colonization of epiphytic C. acuta, a small, stalk-forming xanthophytes standing erect on its filaments as well as on the surface of the substrates. The appearance of Oedogonium sp. was also established in this phase. Thus, only after one week of exposition, periphyton was characterized by a high abundance of C-selected taxa (Cladophora) and C-S-selected taxa (Oedogonium), indicating the formation of "climax" community (Biggs et al., 1998). Generally, filamentous green algae usually colonize periphyton during the late phase of its development and the longer period is necessary to achieve the "climax" community (Biggs et al., 1998; Ács et al., 2000). Metaphyton composed of filamentous green algae C. glomerata, Oedogonium sp. and Mougeotia sp., inhabited by different species of Cyanobacteria, small green algae (e.g., Scenedesmus, Monoraphidium, Pediastrum) and diatoms (e.g., Cocconeis, Cymbella, Fragilaria, Nitzschia, Gomphonema) were intensively developed in the lake from the middle of June. The persistence of metaphyton briefly halted in the first half of the July, probably as a consequence of increased temperatures and high irradiance levels (Goldsborough and Robinson, 1996; Zohary et al., 1998). Considering the fact that C. glomerata was found in metaphyton clouds, its intense development on the glass slides indicates the maintaining of this species and propagules in the water column at the beginning of the study. Water motion and velocity can detach Cladophora from its original substrate, drifting until it becomes wrapped around the new substrata (Dodds and Gudder, 1992). Environmental conditions, e.g., relatively high light, high nutrient concentrations and ambient $\mathrm{pH}$ higher than 7, were favorable for Cladophora development (see Higgins et al., 2008 for review). The RDA analysis (Fig. 7) suggested that water temperature appeared to be a significantly influential factor for its development. The responses to temperature are often used to describe its seasonal abundance in many rivers and lakes. Cladophora dies off in midsummer, which could be caused by an inability to maintain dominance above $23.5^{\circ} \mathrm{C}$ (see Dodds and Gudder, 1992 for review). The new flood pulse that started at the end of July caused highly variable perturbations. Dilution and washout effect of floodwater on phytoplankton abundance was expressed and a significant increase of water transparency and the decrease in chlorophyll a concentration occurred. Periphytic algal community responded quickly to such unstable environment. A significant increase in chlorophyll c concentration (Fig. 4C) was achieved, following the increase of total diatom abundance (late phase, days 18-33). The most abundant species was G. parvulum (Fig. 5C). Following its attachment ability, firmly to the substratum by gelatinous stalk, Gomphonema has a high resistance to removal (Bahulikar, 2006) and a high tolerance to disturbance (Biggs et al., 1998). As an R-strategist it is a strong competitor that has a rapid growth even if resource supplies are low (Biggs et al., 1998) and thus can persist within the mature periphytic communities characterized by high algal abundance, as it was found during the late phase of colonization in our study. However, a significant decrease of total periphyton biomass, chlorophyll concentrations and algal abundance (Figs. 4A, C and 5B) established on day 36, indicated that significant loss processes existed. Death, sloughing and emigration of periphytic organisms together with grazing pressure are most often reasons for significant decrease in periphyton biomass (Azim and Asaeda, 2005). Beside self-generated detachment due to nutrient starvation within periphyton matrix and possibly grazing pressure by periphytic invertebrates, the loss processes were supported by various influences of dense mats of metaphyton and submersed macrophyte $C$. demersum associated with floating macrophytes Salvinia natans (L.) All. and Hydrocharis morsus ranae $\mathrm{L}$. which appeared around the study site and overgrew it after day 33. The increase of grazing pressure on periphyton was expected because macrophyte stands supported a high density of grazing invertebrates such as Rotatoria, Oligochaeta, Nematoda, Insecta larvae and snails (Vidaković, unpublished data) being also attractive for omnivorous fish. As it has been established, fish invertebrate - periphyton cascade may maintain a low periphyton biomass (Jones and Sayer, 2003; Liboriussen et al., 2005; Meerhoff, 2006; Ferreira et al., 2011). Furthermore, movements of submerged macrophytes can sweep away floating filaments of periphytic algae. Heavy shading by a floating cover of macro-algae and macrophytes on the water surface can significantly reduce the light availability necessary for the growth of algal communities (Toet et al., 2003). Altogether, high density of invertebrate grazers and fish, as well as shading and mechanical injuries of periphyton caused by macrophytes and metaphyton stirring, scouring by waves, and probably nutrient deficiency inside the periphyton matrix, appears to have maintained low periphyton biomass. Consequently, structural changes in periphytic algal communities occurred. According to NMDS (Fig. 6), it is evident that community structure had returned to an intermediate phase (days 36-39). In spite of the fact that Oedogonium $\mathrm{sp}$. was attached to the substrata at the beginning of this phase, unfavorable conditions in the lake suppressed its further development. However, on the last day of colonization (day 43), the total algal abundance slightly increased (Fig. 5B) and reached the level of the late phase of colonization due to the high immigration and reproduction rate of dominant diatom species $G$. parvulum and A. minutissimum. The high abundance of these $\mathrm{R}$-strategists indicates natural disturbance (Biggs et al., 1998; Stenger-Kovács et al., 2006). 
Altogether, our data indicate that a strong interrelationship among the changes of abiotic environment and biological components in hydrologically driven complex river-floodplain system can significantly influence periphyton colonization. Flood-induced spreading of metaphyton firstly supported the rapid progress of algal colonization towards a climax community, while later, dense stands of metaphyton together with macrophytes disrupted algal community by increasing the mechanical injuries, shading, and grazing pressure. In conclusion, directional changes in the periphytic algal community during the colonization in a floodplain under the variable environmental conditions in summer may occur in an unpredictable manner, shifting the community back to the early phase of colonization. Further investigations are necessary to elucidate very complex interactions between periphyton and other aquatic biocenoses in river-floodplain systems.

Acknowledgements. This study was supported by the Croatian Ministry of Science, Education and Sports, Research Project no. 285-0000000-2674. We are grateful to project leader Professor Jasna Vidaković for her support. We express our thanks to Branimir K. Hackenberger, PhD for kind advice on experimental design. We are grateful to Boris Kuzman for help with field and laboratory work. We thank the Handling Editor and anonymous reviewers for their constructive comments that help us to substantially improve this manuscript.

\section{References}

Ács É. and Kiss K.T., 1993. Colonization processes of diatoms on artificial substrates in the River Danube near Budapest (Hungary). Hydrobiologia, 269/270, 307-315.

Ács É., Kiss K.T., Szabó K. and Makk J., 2000. Short-term colonization sequence of periphyton on glass slides in a large river (River Danube, near Budapest). Arch. Hydrobiol. Suppl. Algol. Stud., 100, 135-156.

Ács É., Borsodi A.K., Kröpfl K., Vladár P. and Záray G., 2007. Changes in the algal composition, bacterial metabolic activity and element content of biofilms developed on artificial substrata in the early phase of colonization. Acta Bot. Croat., 66, 89-100.

Addisie Y. and Medellin A.C., 2012. Allelopathy in aquatic macrophytes: effects on growth and physiology of phytoplanktons. Afr. J. Plant Sci., 6, 270-276.

Albay M. and Akçaalan R., 2003. Comparative study of periphyton colonisation on common reed (Phragmites australis) and artificial substrate in a shallow lake, Manyas, Turkey. Hydrobiologia, 506-509, 531-540.

Algarte V.M., Siqueira N.S., Murakami E.A. and Rodrigues L., 2009. Effects of hydrological regime and connectivity on the interannual variation in taxonomic similarity of periphytic algae. Braz. J. Biol., 69, 609-616.

Anagnostidis K. and Komárek J., 1985. Modern approach to the classification system of cyanophytes. 1. Introduction. Arch. Hydrobiol. Suppl., 71, 291-302.

Anagnostidis K. and Komárek J., 1988. Modern approach to the classification system of cyanophytes. 3. Oscillatoriales. Arch. Hydrobiol. Suppl., 80, 327-472.
APHA, 1992. Standard Methods for the Examination of Water and Wastewater, 18th edn, American Public Health Association, Washington, DC, 1268 p.

Azim M.E. and Asaeda T., 2005. Periphyton: structure, diversity and colonization. In: Azim M.E., Verdegem M.C.J., van Dam A.A. and Beveridge M.C.M. (eds.), Periphyton: Ecology, Exploitation and Management, CABI Publishing, Wallingford, 15-34.

Azim M.E., Beveridge M.C.M., van Dam A.A. and Verdegem M.C.J., 2005. Periphyton and aquatic production: an introduction. In: Azim M.E., Verdegem M.C.J., van Dam A.A. and Beveridge M.C.M. (eds.), Periphyton: Ecology, Exploitation and Management, CABI Publishing, Wallingford, 1-13.

Bahulikar R.A., 2006. Diatoms from littoral zone of Lake Constance: Diversity, phylogeny, extracellular polysaccharides and bacterial associations. Dissertation zur Erlangung des akademischen Grades des Doktors der Naturwissenschaften (Dr. rer. nat.) an der Universität Konstanz, Fachbereich Biologie, Konstanz, 1-14.

Biggs B.J.F., Stevenson R.J. and Lowe R.L., 1998. A habitat matrix conceptual model for stream periphyton. Arch. Hydrobiol., 143, 21-56.

Borcard D., Legendre P. and Drapeau P., 1992. Partialling out the spatial component of ecological variation. Ecology, 73, 1045-1055.

Clarke K.R. and Warwick R.M., 2001. Change in Marine Communities: An Approach to Statistical Analysis and Interpretation. Plymouth Marine Laboratory, Plymouth, $177 \mathrm{p}$.

Dodds K.W. and Gudder A.D., 1992. The ecology of Cladophora. J. Phycol., 28, 415-427.

Felisberto S.A. and Rodrigues L., 2010. Periphytic algal community in artificial and natural substratum in a tributary of the Rosana reservoir (Corvo Stream, Paraná State, Brazil). Acta Sci. Biol. Sci., 32, 373-385.

Ferreira F.A., Mormul R.P., Thomaz S.M., Pott A. and Pott V.J., 2011. Macrophytes in the upper Paraná river floodplain: checklist and comparison with other large South American wetlands. Rev. Biol. Trop. (Int. J. Trop. Biol.), 59, 541-556.

Gaiser E.E., Scinto L.J., Richards J.H., Jayachandran K., Childers D.L., Trexler J.C. and Jones R.D., 2004. Phosphorus in periphyton mats provides the best metric for detecting low-level P enrichment in an oligotrophic wetland. Wat. Res., 38, 507-516.

Goldsborough L.G. and Robinson G.G.C., 1996. Patterns in wetlands. In: Stevenson R.J., Bothwell M.L. and Lowe R.L. (eds.), Algal Ecology. Freshwater Benthic Ecosystems, Academic Press, USA, 78-120.

Gottlieb A.D., Richards J.H. and Gaiser E.E., 2006. Comparative study of periphyton community structure in long and short hydroperiod Everglades marshes. Hydrobiologia, 569, 195-207.

Gross E.M., Erhard D. and Iványi E., 2003. Allelopathic activity of Ceratophyllum demersum L. and Najas marina ssp. intermedia (Wolfgang) Casper. Hydrobiologia, 506, 583-589.

Guasch H., Admiraal W. and Sabater S., 2003. Contrasting effects of organic and inorganic toxicants on freshwater periphyton. Aquat. Toxicol., 64, 165-175.

Higgins S. and Hann B.J., 1995. Snail grazer-periphyton interactions: the effects of macrophyte removal, inorganic 
nutrient addition, and organic nutrient addition. UFS (Delta Marsh) Annual Report, 30, 28-37.

Higgins S.N., Malkin S.Y., Howell E.T., Guildford S.J., Campbell L., Hiriart-Baer V. and Hecky R.E., 2008. An Ecological Review of Cladophora glomerata (Chlorophyta) in the Laurentian Great Lakes. J. Phycol., 44, 839-854.

Hindak F., Cyrus Z., Marvan P., Javornicky P., Komarek J., Etll H., Rosa K., Sladečkova A., Popovsky J., Punčocharova M. and Lhotsky O., 1978. Slatkovodne riasy. Slovenske pedagogicke nakladelstvo, Bratislava.

Hoagland K.D., Roemer S.C. and Rosowski J.R., 1982. Colonization and community structure of two periphyton assemblages with emphasis on the diatoms (Bacillariophyceae). Am. J. Bot., 69, 188-213.

Horvatić J., Mihaljević M. and Stević F., 2003. Algal growth potential of Chlorella kessleri Fott et Nov. in comparison with in situ microphytoplankton dynamics in the water of Lake Sakadaš marshes. Period. Biol., 105, 307-312.

Huber-Pestalozzi G., 1942. Das Phytoplankton des Süßwassers. Systematik und Biologie. Teil. 2. - E. Schweizerbart'śche Verlagsbuchhandlung (Erwin Nägele), Stuttgart.

Hustedt F., 1976. Bacillariophyta, Otto Koeltz Science Publishers, Koenigstein.

Jones I.J. and Sayer C.D., 2003. Does the fish - invertebrate periphyton cascade precipitate plant loss in shallow lakes? Ecology, 84, 2155-2167.

Komárek J. and Anagnostidis K., 1989. Modern approach to the classification system of cyanophytes. 4. Nostocales. Algol. Stud., 56, 247-345.

Komárková J., 1989. Primárni produkce ř as ve slatkovodních ekosysteméch. In: Dykyová D. (ed.), Metody studia ecosystémů, Academia Praha, Praha, 330-347.

Lakatos G., 1989. Composition of reed periphyton (biotecton) in the Hungarian part of lake Fertö. Biol. Forschun., 71, $125-134$.

Lepš J. and Šmilauer P., 2003. Multivariate Analysis of Ecological Data using Canoco, Cambridge University Press, Cambridge, $267 \mathrm{p}$.

Liboriussen L., 2003. Production, regulation and ecophysiology of periphyton in shallow freshwater lakes. $\mathrm{PhD}$ thesis. National Environmental Research Institute, Department of Freshwater Ecology, Faculty of Science, University of Aarhus, Denmark, 47 p.

Liboriussen L., Jeppesen E., Bramm M.E. and Lassen M.F., 2005. Periphyton-macroinvertebrate interactions in light and fish manipulated enclosures in a clear and a turbid shallow lake. Aquat. Ecol., 39, 23-39.

MacArthur R.H. and Wilson E.O., 1963. An equilibrium theory of insular zoogeography. Evolution, 17, 373-387.

Meerhoff M., 2006. The structuring role of macrophytes on trophic dynamics in shallow lakes under a climate-warming scenario. PhD thesis. Faculty of Science, University of Aarhus, Denmark.

Mihaljević M. and Stević F., 2011. Cyanobacterial blooms in a temperate river-floodplain ecosystem: the importance of hydrological extremes. Aquat. Ecol., 45, 335-349.
Mihaljević M. and Žuna Pfeiffer T., 2012. Colonization of periphyton algae in a temperate floodplain lake under a fluctuating spring hydrological regime. Fundam. Appl. Limnol., 180, 13-25.

Mihaljević M., Getz D., Tadić Z., Živanović B., Gucunski D., Topić J., Kalinović I. and Mikuska J., 1999. Kopački Rit Research Survey and Bibliography, Croatian Academy of Arts and Sciences, Zagreb, 188 p.

Mihaljević M., Stević F., Horvatić J. and Hackenberger Kutuzović B., 2009. Dual impact of the flood pulses on the phytoplankton assemblages in a Danubian floodplain lake (Kopački Rit Nature Park, Croatia). Hydrobiologia, $618,77-88$.

Morin S., Pesce S., Tlili A., Coste M. and Montuelle B., 2010. Recovery potential of periphytic communities in a river impacted by a vineyard watershed. Ecol. Indic., 10, 419-426.

Murakami E.A., Bicudo D.C. and Rodrigues L., 2009. Periphytic algae of the Garças Lake, Upper Paraná River floodplain: comparing the years 1994 and 2004. Braz. J. Biol., 69, 459-468.

Rodrigues L. and Bicudo D.C., 2001. Similarity among periphyton algal communities in a lentic-lotic gradient of the upper Paraná river floodplain, Brazil. Revta Brasil. Bot., 24, 235-248.

Sekar R., Venugopalan V.P., Nandakumar K., Nair K.V.K. and Rao V.N.R., 2004. Early stages of biofilm succession in a lentic freshwater environment. Hydrobiologia, 512, 97-108.

Stenger-Kovács C., Padisák J. and Bíró P., 2006. Temporal variability of Achnanthidium minutissimum (Kützing) Czarnecki and its relationship to chemical and hydrological features of the Torna-stream, Hungary. In 6th Int. Symposium on Use of algae for monitoring rivers. Hungary, Balatonfüred.

Stilinović B. and Plenković-Moraj A., 1995. Bacterial and phytoplanktonic research of Ponikve artificial lake on the island of Krk. Period. Biol., 97, 351-358.

Szabó K.E., Makk J., Kiss K.T., Eiler A., Ács E., Tóth B., Kiss Á.K. and Bertilsson S., 2008. Sequential colonization of river periphyton analysed by microscopy and molecular fingerprinting. Freshwat. Biol., 53, 1359-1371.

Tockner K., Malard F. and Ward J.V., 2000. An extension of the flood pulse concept. Hydrol. Process., 14, 2861-2883.

Toet S., Hersbach L. and Verhoeven J.T.A., 2003. Periphyton biomass and nutrient dynamics in a treatment wetland in relation to substratum, hydraulic retention time and nutrient removal. Arch. Hydrobiol. Suppl., 139, 361-392.

Ward J.V. and Stanford J.A., 1995. Ecological connectivity in alluvial river ecosystems and its disruption by flow regulation. Regul. Rivers Res. Manage., 11, 105-119.

Zohary T., Fishbein T., Kaplan B. and Pollingher U., 1998. Phytoplankton-metaphyton seasonal dynamics in a newly-created subtropical wetland lake. Wet. Ecol. Manag., $6,133-142$. 